Reseacen

\title{
PKC and ERK mediate GH-stimulated lipolysis
}

\author{
Heather E Bergan, Jeffrey D Kittilson and Mark A Sheridan
}

Department of Biological Sciences, North Dakota State University, Fargo, North Dakota 58105, USA

Correspondence should be addressed

to M A Sheridan

Email

mark.sheridan@ndsu.edu

\begin{abstract}
$\mathrm{GH}$ regulates several physiological processes in vertebrates, including the promotion of growth, an anabolic process, and the mobilization of stored lipids, a catabolic process. In this study, we used hepatocytes isolated from rainbow trout (Oncorhynchus mykiss) as a model to examine the mechanism of GH action on lipolysis. GH stimulated lipolysis as measured by increased glycerol release in both a time- and a concentration-related manner. The promotion of lipolysis was accompanied by GH-stimulated phosphorylation of the lipolytic enzyme hormone-sensitive lipase (HSL). GH-stimulated lipolysis was also manifested by an increased expression of the two HSL-encoding mRNAs, HSL1 and HSL2. The signaling pathways that underlie $\mathrm{GH}$-stimulated lipolysis were also studied. $\mathrm{GH}$ resulted in the activation of phospholipase $C$ (PLC)/protein kinase $C$ (PKC) and the MEK/ERK pathway, whereas JAK-STAT and the PI3K-Akt pathway were deactivated. The blockade of PLC/PKC and the MEK/ERK pathway inhibited GH-stimulated lipolysis and GH-stimulated phosphorylation of HSL as well as GH-stimulated HSL mRNA expression, whereas the blockade of JAK-STAT or the PI3K-Akt pathway had no effect on the activation of lipolysis or the expression of HSL stimulated by GH. These results indicate that GH promotes lipolysis by activating HSL and by enhancing the de novo expression of HSL mRNAs via the activation of PKC and ERK. These findings also suggest molecular mechanisms for activating the lipid catabolic actions of $\mathrm{GH}$ while simultaneously deactivating anabolic processes such as antilipolysis and the growth-promoting actions of $\mathrm{GH}$.
\end{abstract}

\author{
Key Words \\ - signal transduction \\ $\checkmark \mathrm{GH}$ \\ - lipids \\ - metabolism \\ - hormone-sensitive lipase \\ - rainbow trout \\ (Oncorhynchus mykiss)
}

Journal of Molecular

Endocrinology

(2013) 51, 213-224

\section{Introduction}

Lipids play many roles in animals, but their most significant use is as an energy reserve; therefore, the breakdown of stored lipids (lipolysis) is a critical aspect of their metabolism (Sheridan 1988). The main lipolytic enzyme is hormone-sensitive lipase (HSL; Watt \& Spriet 2010). HSL has been characterized in the adipose tissue of mammals (Lafontan \& Langin 2009) and in the adipose tissue and liver of fish (Sheridan 1994). Interestingly, fish possess two $H S L$-encoding mRNAs that are differentially expressed among tissues (Kittilson et al. 2011). In mammals (Watt \& Steinberg 2008) and fish (Sheridan 1994), HSL exists in two catalytic states and, upon activation by phosphorylation, hydrolyzes triacylglycerol (TG) to glycerol and fatty acids (FAs).

Numerous hormones stimulate HSL in mammals and fish, most notably glucagon and catecholamines, which act through protein kinase A (PKA; Sheridan 1994, González-Yanes \& Sánchez-Margalet 2006). By contrast, insulin (INS) is lipogenic in mammals and fish as well as directly antilipolytic (via dephosphorylation of HSL) (Harmon et al. 1993, Albalat et al. 2007, Chaves et al. 2011). The effects of GH define on lipid metabolism are complex,

Published by Bioscientifica Ltd. 
and short-term INS-like (antilipolytic) and long-term antiINS-like (lipolytic) effects have been reported in mammals (Carrel \& Allen 2000, Chaves et al. 2011). INS-like effects can be observed in adipose tissue not exposed to GH previously (i.e. from hypophysectomized animals or from cells of normal individuals preincubated in the absence of GH for 2-4 h), whereas continued exposure to GH results in lipolysis (Carrel \& Allen 2000). Given the conditions under which the INS-like effects are brought about, their biological significance has been questioned (Carrel \& Allen 2000). The lipolytic effect of GH in fish was first demonstrated in the adipose tissue and liver of salmon in vivo. GH implantation stimulated HSL activity, whereas hypophysectomy reduced it, an effect that was reversed by GH replacement (cf. Sheridan (1994)). Subsequently, GH has been shown to directly stimulate lipolysis by us in liver isolated from rainbow trout (O'Connor et al. 1993) and others in adipose tissue isolated from sea bream (Albalat et al. 2005).

Despite extensive knowledge of GH signal transduction (Waters et al. 2006), the mechanism(s) by which GH enhances lipolysis as well as how these mechanisms integrate with other actions of GH (e.g. growth, reproduction, and osmoregulation; Bjornsson et al. 2004, Norrelund 2005) in any species is (are) unclear. In this study, we used rainbow trout hepatocytes as a model to examine the mechanism of GH action on lipolysis. This system is particularly advantageous because trout liver cells possess a high abundance of GH receptors (GHRs; Reindl \& Sheridan 2012) and are a significant lipid storage site with a well-characterized lipolytic system (Sheridan 1994). Our specific hypothesis was that ERK and PKC mediate GH-stimulated lipolysis. The rationale for this hypothesis extends from our previous observations that hepatic lipolysis and plasma GH levels increased during periods of food deprivation (Norbeck et al. 2007) and that fasting-induced lipolysis in trout liver was accompanied by the deactivation of Akt, JAK2, and STAT5 and by the activation of ERK and PKC (Bergan et al. 2012).

\section{Materials and methods}

\section{Materials}

All chemicals were obtained from Sigma, unless stated otherwise. Antibodies for the phospho-specific and total (recognizing both phosphorylated and nonphosphorylated protein) forms of Akt, ERK1/2, JAK2, PKC $\alpha / \beta$ II, and STAT5, HRP-linked anti-rabbit IgG antibody, biotinylated molecular weight marker, anti-biotin-HRP antibody, MEK1/2 inhibitor U0126 (MEK1 and MEK2 are directly responsible for the activation of ERK), PI3K inhibitor LY294002 (PI3K produces phosphatidylinositol phosphates that are critical for the activation of Akt by phosphoinositide-dependent kinase 1 (PDK1)), PKA inhibitor H-89 dihydrochloride (selective for cAMPdependent PKA), and cell lysis buffer were all obtained from Cell Signaling Technology (Beverly, MA, USA). The JAK2 inhibitor 1,2,3,4,5,6-hexabromocyclohexane (Hex), the STAT5 inhibitor $N^{\prime}$-((4-oxo-4H-chromen-3-yl) methylene)nicotinohydrazide (Nico), the Akt inhibitor 1L6-hydroxymethyl-chiro-inositol-2-(R)-2-O-methyl-3-Ooctadecyl-sn-glycerocarbonate (Carb), the broad-spectrum PKC inhibitor chelerythrine chloride (CC), and the broad-spectrum phospholipase C (PLC) inhibitor U73122 were obtained from EMD Chemicals (Gibbstown, NJ, USA). Molecular weight markers were purchased from Bio-Rad Laboratories. Salmonid GH, obtained from Drs Akiyosi Takahasi and Shiunsuke Moriyama, was used for all the experiments.

\section{Experimental animals and conditions}

Juvenile rainbow trout of both sexes ( $\sim 1$ year of age) were obtained from Dakota Trout Ranch (Carrington, ND, USA). Fish were transported to North Dakota State University, where they were maintained in 8001 circular tanks supplied with recirculated (10\% make-up volume/day) water at $14{ }^{\circ} \mathrm{C}$ under a $12 \mathrm{~h}$ light: $12 \mathrm{~h}$ darkness photoperiod. Fish were fed twice daily to satiety with AquaMax Grower (PMI Nutrition International, Brentwood, MO, USA), except 7 days prior to the experiments. Seven-day fasted fish were used because we had shown previously that they were in a catabolic state and capable of undergoing lipolysis (Bergan et al. 2012). Fish were acclimatized to laboratory conditions for at least 4 weeks. All procedures that were carried out were in accordance with the Guide for Care and Use of Laboratory Animals (National Research Council, Washington, DC, USA) and approved by the North Dakota State University Institutional Animal Care and Use Committee.

For the experiments, fish were anesthetized by immersion in $0.05 \%(\mathrm{v} / \mathrm{v})$ 2-phenoxyethanol and killed by transection of the spinal cord. Hepatocytes were isolated by in situ perfusion (Mommsen et al. 1994). The isolated cells were incubated in a recovery medium (in mM: $137.8 \mathrm{NaCl}, 5.4 \mathrm{KCl}, 0.80 \mathrm{MgSO}_{4}, 0.4 \mathrm{KH}_{2} \mathrm{PO}_{4}$, $0.34 \mathrm{Na}_{2} \mathrm{HPO}_{4}, 4.2 \mathrm{NaHCO}_{3}, 10$ HEPES, 0.65 glucose, $\mathrm{pH} 7.6$, with $2 \%$ defatted BSA, $2 \mathrm{ml}$ MEM amino acid mix $(50 \times) / 100 \mathrm{ml}$, and $1 \mathrm{ml}$ nonessential amino acid mix

Published by Bioscientifica Ltd. 
$(100 \times) / 100 \mathrm{ml})$ for $2 \mathrm{~h}$ at $14{ }^{\circ} \mathrm{C}$ with gyratory shaking (100 r.p.m. under $100 \% \mathrm{O}_{2}$ ). Cell viability was assessed by trypan blue dye exclusion, and it ranged between 93 and $97 \%$ for all the experiments. After recovery, hepatocytes were collected by centrifugation $(550 \boldsymbol{g}$ for $8-10 \mathrm{~min})$ and resuspended in an incubation medium (recovery medium with $1.5 \mathrm{mM} \mathrm{CaCl}_{2}$ ) to a final concentration of $6-8 \times 10^{6}$ cells $/ \mathrm{ml}$ and aliquoted into 24 -well plates $\left(6-8 \times 10^{6}\right.$ cells/well). The cells were incubated in the medium alone (control) or in the medium with GH as specified in the figure legends under conditions the same as those used for recovery $\left(14{ }^{\circ} \mathrm{C}\right.$ with gyratory shaking at 100 r.p.m. under $100 \% \mathrm{O}_{2}$ ). In combination experiments involving pathway inhibition, inhibitors were added $2 \mathrm{~h}$ prior to GH treatment at concentrations specifically recommended by the manufacturer and/or used by us previously (Reindl et al. 2011) as follows: $20 \mu \mathrm{M} \mathrm{LY294002,}$ $25 \mu \mathrm{M}$ Carb, $10 \mu \mathrm{M}$ U0126, $50 \mu \mathrm{M}$ Hex, $200 \mu \mathrm{M}$ Nico, $10 \mu \mathrm{M}$ CC, $10 \mu \mathrm{M}$ U73122, and $2.5 \mu \mathrm{M} \mathrm{H}-89$ dihydrochloride. After incubation, the cells were pelleted $(1000 \boldsymbol{g}$ for $4 \mathrm{~min}$ ) and the supernatant was removed. The cells were washed with $0.5 \mathrm{ml}$ PBS. Cell pellets and medium samples were immediately frozen on dry ice and then stored at $-80^{\circ} \mathrm{C}$ until further analysis.

\section{HSL mRNA expression}

Total RNA was extracted using TRI Reagent (Molecular Research Center, Inc., Cincinnati, OH, USA) as specified by the manufacturer's protocol. Each RNA pellet was redissolved in 35-200 $\mu$ l RNase-free deionized water and quantified using NanoDrop1000 spectrophotometer (Thermo Scientific, West Palm Beach, FL, USA). RNA samples were then stored at $-80^{\circ} \mathrm{C}$ until further analysis. mRNA was reverse-transcribed in $5 \mu \mathrm{l}$ reaction using 150 ng total RNA and AffinityScript QPCR cDNA Synthesis kit reagents (Master Mix, random primers, oligo-dT primers, and reverse transcriptase with block) according to the manufacturer's protocol (Stratagene, La Jolla, CA, USA). Reactions without reverse transcriptase were included as negative controls to exclude the possibility of contamination from genomic DNA; no amplification was detected in negative controls.

Steady-state levels of HSL1 and HSL2 mRNAs were determined by quantitative real-time PCR as described previously (Kittilson et al. 2011). Briefly, real-time reactions were carried out for samples, standards, and no-template controls in multiplex reactions with HSL1 or HSL2 and $\beta$-actin. Reaction mixtures contained $2 \mu \mathrm{l}$ cDNA from the RT reactions, $5 \mu$ l Brilliant II QPCR Master Mix
(Stratagene), $1 \mu \mathrm{l}$ of each $150 \mathrm{nM}$ gene-specific probes, $0.5 \mu \mathrm{l}$ of $600 \mathrm{nM}$ gene-specific forward and reverse primers, and $0.15 \mu$ l reference dye (Stratagene, Agilent Technologies). Cycling parameters were as follows: $95^{\circ} \mathrm{C}$ for $10 \mathrm{~min}$ and 45 cycles of $95^{\circ} \mathrm{C}$ for $30 \mathrm{~s}$ and $58^{\circ} \mathrm{C}$ for $1 \mathrm{~min}$. Cross reaction was assessed by substituting alternate primer/probe sets in assays for each standard; no amplification was observed under these conditions. Sample copy number was calculated from the threshold cycle number $\left(C_{\mathrm{T}}\right)$ and relating $C_{\mathrm{T}}$ to a gene-specific standard curve, followed by normalization to $\beta$-actin.

\section{Western blot analysis}

The cells were homogenized in $300 \mu \mathrm{l}$ of $1 \times$ cell lysis buffer (Cell Signaling Technology) with $1 \mathrm{mM}$ PMSF, $1 \times$ protease inhibitor (Calbiochem, San Diego, CA, USA), and $1 \times$ phosphatase inhibitor (G-Biosciences, St Louis, MO, USA). The homogenate was incubated on ice for $5 \mathrm{~min}$ and then centrifuged at $16000 \mathrm{~g}$ for $10 \mathrm{~min}$ at $4{ }^{\circ} \mathrm{C}$. The protein concentration of the supernatant was determined by the Bio-Rad dye-binding method. Protein $(50 \mu \mathrm{g})$ was separated by SDS-PAGE (7.5\% running gel) and transferred onto $0.45 \mu \mathrm{m}$ nitrocellulose membranes (Bio-Rad Laboratories) for western blot analysis (Reindl et al. 2011, Bergan et al. 2012). The membranes were washed and visualized with chemiluminescence according to the manufacturer's instructions (GE Healthcare, Buckinghamshire, UK); chemiluminescence was detected directly, and the bands were quantified with a FluorChem FC2 imager (Alpha Innotech Corp., San Leandro, CA, USA). The abundance of phosphorylated ERK 1/2, Akt, JAK2, STAT5, and PKC $\alpha / \beta$ II was normalized to total ERK 1/2, Akt, JAK2, STAT5, and $\beta$-actin respectively. The use of these commercial antisera to detect signal elements and of pharmacological pathway inhibitors in rainbow trout has been validated previously (Reindl et al. 2011, Bergan et al. 2012).

\section{Glycerol analysis}

Medium samples were deproteinated $\left(65^{\circ} \mathrm{C}\right.$ for $\left.10 \mathrm{~min}\right)$ and then centrifuged $(16000 \mathrm{~g}$ for $10 \mathrm{~min}$ at room temperature). An aliquot of the supernatant was added to a microplate well containing buffer $\mathrm{A}\left(0.205 \mathrm{M} \mathrm{K}_{2} \mathrm{CO}_{3}\right.$, $0.205 \mathrm{M} \mathrm{KHCO}_{3}, \mathrm{pH} 10.0$, and $\left.0.65 \mathrm{M}\left(\mathrm{NH}_{4}\right)_{2} \mathrm{SO}_{4}\right), \mathrm{NAD}^{+}$ (10 $\mathrm{mM}$ in buffer $\mathrm{A}$ ) and glycerol dehydrogenase (7 units $/ \mathrm{ml}$ in buffer B $\left(4.76 \mathrm{mM} \mathrm{KH}_{2} \mathrm{PO}_{4}, 4.76 \mathrm{mM} \mathrm{K}_{2} \mathrm{HPO}_{4}, \mathrm{pH} 7.6\right.$, $1.4 \mu \mathrm{M} \mathrm{MnCl}_{2}$, and $\left.\left.0.9 \mu \mathrm{M}\left(\mathrm{NH}_{4}\right)_{2} \mathrm{SO}_{4}\right)\right)$, in a $4: 2: 1: 1$ ratio,

Published by Bioscientifica Ltd. 
respectively, in a total volume of $200 \mu \mathrm{l}$. Mixtures were incubated at $25^{\circ} \mathrm{C}$ for $1 \mathrm{~h}$, and then $\mathrm{A}_{340}$ was measured.

\section{Hormone-modulated phosphorylation}

GH-regulated phosphorylation of HSL was determined in hepatocytes according to the method of Harmon et al. (1993). Four million cells were preincubated in $0.46 \mathrm{ml}$ Hank's buffer (in mM: $137.8 \mathrm{NaCl}, 5.37 \mathrm{KCl}, 0.8$ $\mathrm{MgSO}_{4}, 0.4 \mathrm{KH}_{2} \mathrm{PO}_{4}, 0.337 \mathrm{Na}_{2} \mathrm{HPO}_{4}, 4.17 \mathrm{NaHCO}_{3}, 10.0$ HEPES, and 4 glucose, $\mathrm{pH} 7.6)$ with $4 \mu \mathrm{Ci}\left[{ }^{32} \mathrm{P}\right]$-monopotassium phosphate (specific activity $1000 \mathrm{mCi} / \mathrm{mM}$; MP Biomedicals, Santa Ana, CA, USA) in the presence or absence of pathway inhibitors at the concentrations described above for $3 \mathrm{~h}$ at $14{ }^{\circ} \mathrm{C}$ with gyratory shaking at 100 r.p.m. under $100 \% \mathrm{O}_{2}$. The cells were collected by centrifugation (550 r.p.m. for 8-10 min), washed twice with Hank's buffer, and then dispersed and incubated in Hank's buffer with or without $\mathrm{GH}$ at $100 \mathrm{ng} / \mathrm{ml}$ for $3 \mathrm{~h}$ at $14{ }^{\circ} \mathrm{C}$ with gyratory shaking at 100 r.p.m. under $100 \% \mathrm{O}_{2}$. Incubations were stopped by centrifugation $(1000 \boldsymbol{g}$ for 4 min at $14^{\circ} \mathrm{C}$ ). The cells were resuspended in Hank's buffer and homogenized. Following centrifugation ( $16000 \mathrm{~g}$ for $10 \mathrm{~min}$ at $14{ }^{\circ} \mathrm{C}$ ), the supernatant was removed, separated, and subjected to $20 \%$ ammonium sulfate fractionation; the HSL-containing precipitate (Harmon et al. 1991) was collected after ice incubation (30 min) and centrifugation (16000 $\boldsymbol{g}$ for $15 \mathrm{~min})$. HSL samples were resuspended in a buffer $(25 \mathrm{mM}$ Tris- $\mathrm{HCl}, \mathrm{pH}$ 7.4) and subjected to SDS-PAGE. $\left[{ }^{32} \mathrm{P}\right]$-phosphorylatedHSL was detected by direct phosphor imaging (Packard Cyclone) of gels.

\section{Statistical analysis}

Statistical differences were estimated by one- or two-way ANOVA, as appropriate. In all the cases, main effects were significant, and no significant interactions were observed between the main effects in two-way ANOVAs. After determining that data were normally distributed and displayed equal variance, pairwise comparison of simple effects was made using Duncan's multiple range test; statistical notations in the figures reflect such comparisons. A P level of 0.05 was used to indicate significance. All statistical analyses were performed on untransformed data using SigmaStat v. 1.0 (SPSS), and graphs and curve-fitting models (for concentration response and computation of $\mathrm{ED}_{50} \mathrm{~s}$ ) were constructed with SigmaPlot v8.0 (SPSS). Quantitative data are reported relative to the control for ease of comparison and are expressed as means \pm s.E.M.

\section{Results}

\section{GH stimulates lipolysis in isolated hepatocytes}

The lipolysis of stored lipids by HSL results in the release of glycerol into the culture medium. GH stimulated lipolysis as assessed by glycerol release in a time-related manner (Fig. 1A). Initial glycerol levels in the medium were $8.4 \pm 1.3 \mu \mathrm{M} / 10^{6}$ cells, and within $1 \mathrm{~h}$ of $\mathrm{GH}$ exposure, glycerol levels increased significantly. Maximum glycerol release was observed after $6 \mathrm{~h}$; thereafter, glycerol concentration declined. GH also stimulated glycerol release in a concentration-related manner (Fig. 1B). Basal glycerol release was $8.7 \pm 1.3 \mu \mathrm{M} / 10^{6}$ cells. $\mathrm{GH}$ led to a significant increase in glycerol release at
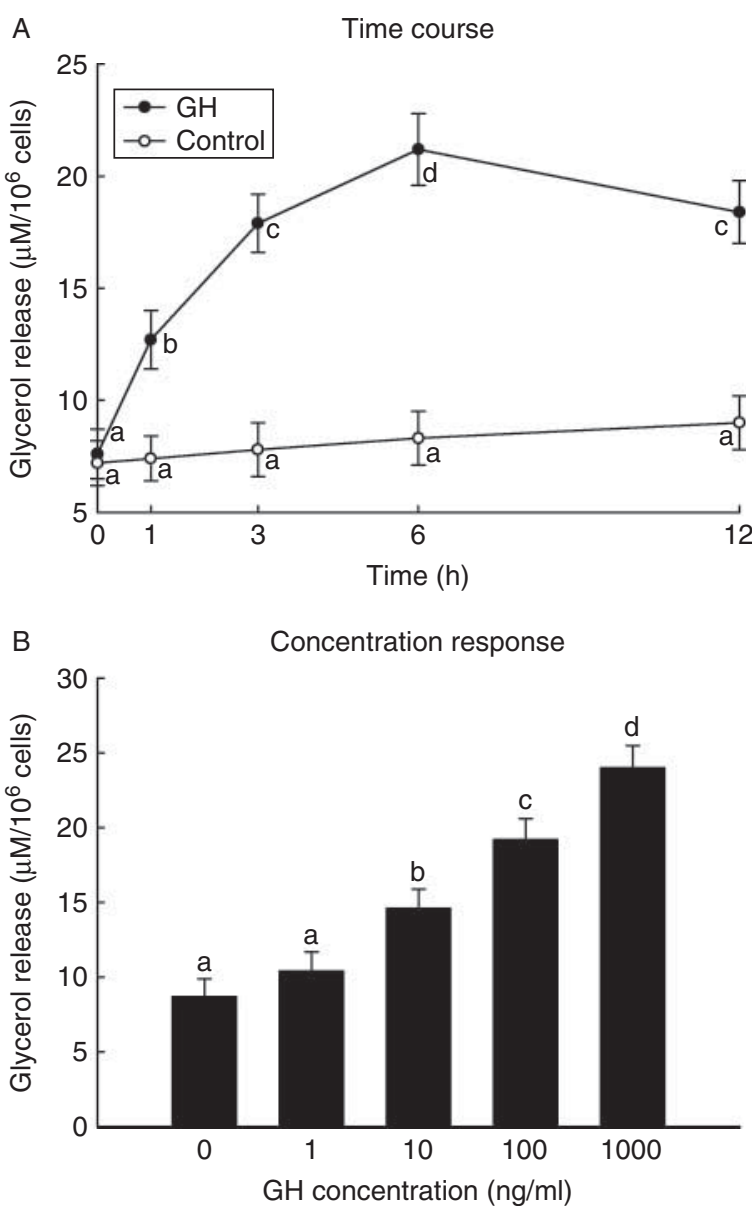

Figure 1

GH-stimulated lipolysis as measured by glycerol release in hepatocytes isolated from rainbow trout fasted for 7 days. (A) Time-dependent glycerol release from cells incubated with $100 \mathrm{ng} / \mathrm{ml} \mathrm{GH}$. (B) Concentrationdependent glycerol release from cells incubated in the absence or presence of various concentrations of $\mathrm{GH}$ for $6 \mathrm{~h}$. Data are presented as means \pm s.E.M. $(n=8)$. Groups with different letters are significantly $(P<0.05)$ different.

Published by Bioscientifica Ltd. 
$10 \mathrm{ng} / \mathrm{ml}$, and maximum glycerol release was observed at a GH concentration of $1000 \mathrm{ng} / \mathrm{ml}$.

The effect of GH on the activation of HSL was studied in isolated hepatocytes that were preincubated with $\left[{ }^{32} \mathrm{P}\right]$-monopotassium phosphate. GH stimulated the phosphorylation of HSL as evidenced by the increased radioactive signal in the HSL fraction when compared with the untreated control (Fig. 2). The increased phosphorylation of HSL was observed after a 3-h incubation of $\mathrm{GH}$ at $100 \mathrm{ng} / \mathrm{ml}$. Taken together, these findings suggest that GH stimulates lipolysis through the phosphorylation of HSL.

The possibility that GH promotes lipolysis by stimulating the expression of $H S L$ mRNAs was also investigated. Rainbow trout possess two HSL-encoding mRNAs, HSL1 and HSL2; both forms were detected in all the samples of hepatocytes. GH stimulated the expression of both HSL1 and HSL2 mRNAs in a time-dependent manner (Fig. 3A). GH significantly increased the expression of $H S L$ mRNAs within $3 \mathrm{~h}$. Maximum stimulation occurred after $12 \mathrm{~h}$ of GH treatment, increasing 275 and $300 \%$ for HSL1 and HSL2 mRNAs respectively. By $24 \mathrm{~h}$ of GH treatment, expression decreased significantly from peak values, but not to the levels observed in controls. The pattern of expression of HSL 1 and HSL 2 mRNAs differed significantly only after $3 \mathrm{~h}$ of GH treatment, with HSL2 mRNA being expressed to a greater extent than HSL1 mRNA. GH also

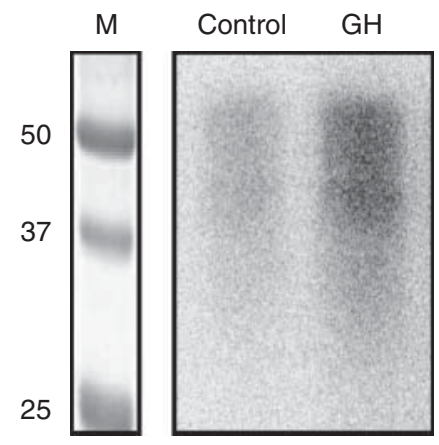

Figure 2

$\mathrm{GH}$-stimulated phosphorylation of HSL in hepatocytes isolated from rainbow trout fasted for 7 days. Hepatocytes were preincubated with $\left[{ }^{32} \mathrm{P}\right]-$ monopotassium phosphate for $3 \mathrm{~h}$, after which the cells were treated with or without (control) GH at $100 \mathrm{ng} / \mathrm{ml}$ for another $3 \mathrm{~h}$. HSL was purified from the isolated hepatocytes by ammonium sulfate fractionation, and the phosphorylated enzyme was separated by SDS-PAGE and detected by autoradiography as described in the Materials and methods section. ${ }^{32} \mathrm{P}$-phosphorylation of HSL was stimulated by incubation with GH. Lane 1, control; lane 2, GH; M, molecular weight marker. The image shown is a representative autoradiogram from three independent experiments.
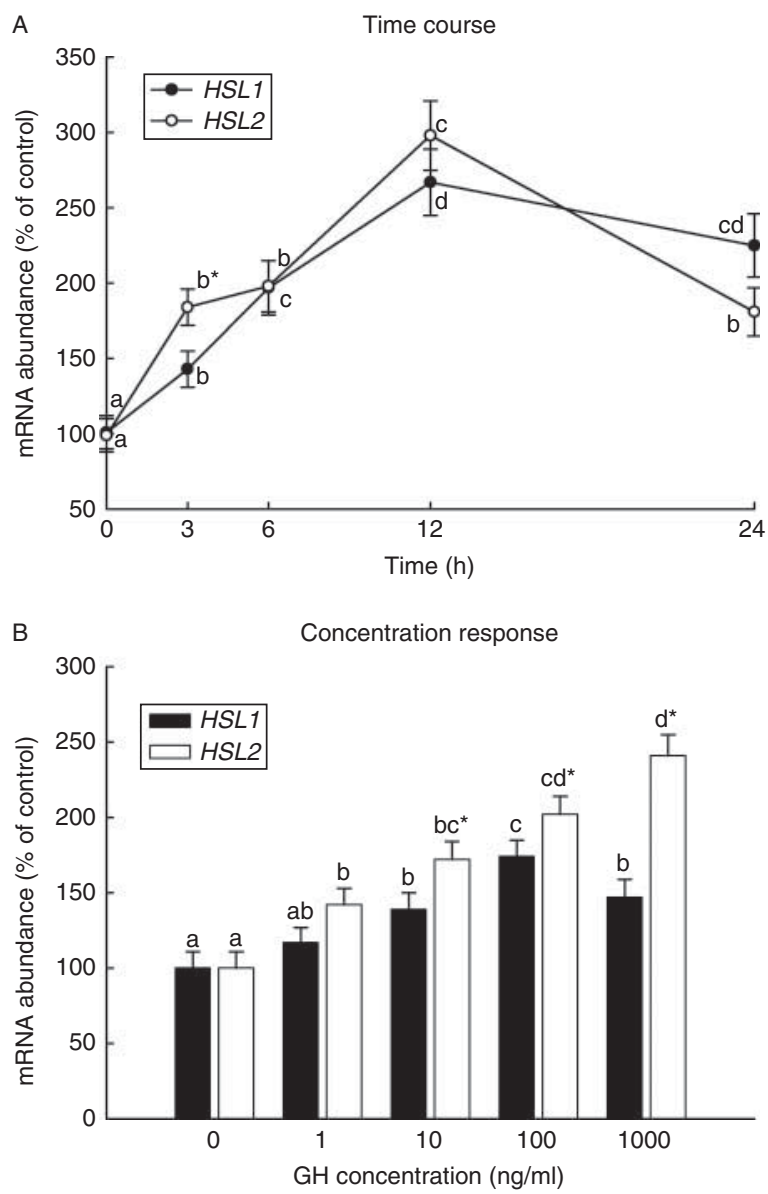

Figure 3

GH-stimulated expression of HSL1- and HSL2-encoding mRNAs in hepatocytes isolated from rainbow trout fasted for 7 days. (A) Time-dependent HSL mRNA expression in cells incubated with $100 \mathrm{ng} / \mathrm{ml} \mathrm{GH}$.

(B) Concentration-dependent HSL mRNA expression in cells incubated in the absence or presence of various concentrations of GH for $6 \mathrm{~h}$. Steadystate levels of mRNA were determined by quantitative real-time RT-PCR as described in the Materials and methods section. Data are presented as percent of control ((A) $0 \mathrm{ng} / \mathrm{ml} \mathrm{GH}$ at each respective time point; (B) $0 \mathrm{ng} / \mathrm{ml}$ $\mathrm{GH})$ and expressed as means \pm s.E.M. $(n=6)$. For a given HSL isoform, groups with different letters are significantly $(P<0.05)$ different; *significant difference between HSL subtypes in cells treated with GH for a given time or at a given concentration.

stimulated both HSL1 and HSL2 mRNAs in a concentration-related manner (Fig. 3B). Notably, GH was more potent in stimulating the expression of HSL2 mRNA than that of HSL1 mRNA. The expression of HSL2 mRNA was significantly stimulated over control levels at a concentration of $1 \mathrm{ng} / \mathrm{ml}$, whereas that of HSL2 mRNA was significantly increased over control levels at $10 \mathrm{ng} / \mathrm{ml} \mathrm{GH}$. There was also a significant difference between the expression of HSL2 mRNA and that of HSL1 mRNA evoked by $\mathrm{GH}$ at 10,100 , and $1000 \mathrm{ng} / \mathrm{ml}$; and at a $\mathrm{GH}$

Published by Bioscientifica Ltd. http://jme.endocrinology-journals.org DOI: 10.1530/JME-13-0039
๑) 2013 Society for Endocrinology Printed in Great Britain 
concentration of $1000 \mathrm{ng} / \mathrm{ml}$, the expression of HSL1 mRNA declined from the maximum level observed at $100 \mathrm{ng} / \mathrm{ml}$.

\section{GH selectively deactivates/activates signaling pathways}

The activation of cell signaling pathways by GH was studied in lysates from hepatocytes isolated from fish fasted for 7 days probed with phospho-specific and control antibodies. Phospho-JAK2, phospho-STAT5, phospho-Akt, phospho-ERK, and phospho-PKC were detected in all the treated hepatocytes. GH deactivated JAK2, STAT5, and Akt in a time-related manner (Fig. 4A, C and E). Significant deactivation of both JAK2 and Akt, a downstream target of PI3K, occurred within $5 \mathrm{~min}$, and then the levels returned to control levels by $1 \mathrm{~h}$ of GH treatment. STAT5 was significantly deactivated within $10 \mathrm{~min}$, an effect that persisted through $3 \mathrm{~h}$. GH also deactivated JAK2, STAT5, and Akt in a concentration-related manner (Fig. 4B, D and F). Significant deactivation of JAK2, STAT5, and Akt occurred initially at a concentration of $10 \mathrm{ng} / \mathrm{ml} \mathrm{GH}$, and progressively lower degrees of phosphorylation were
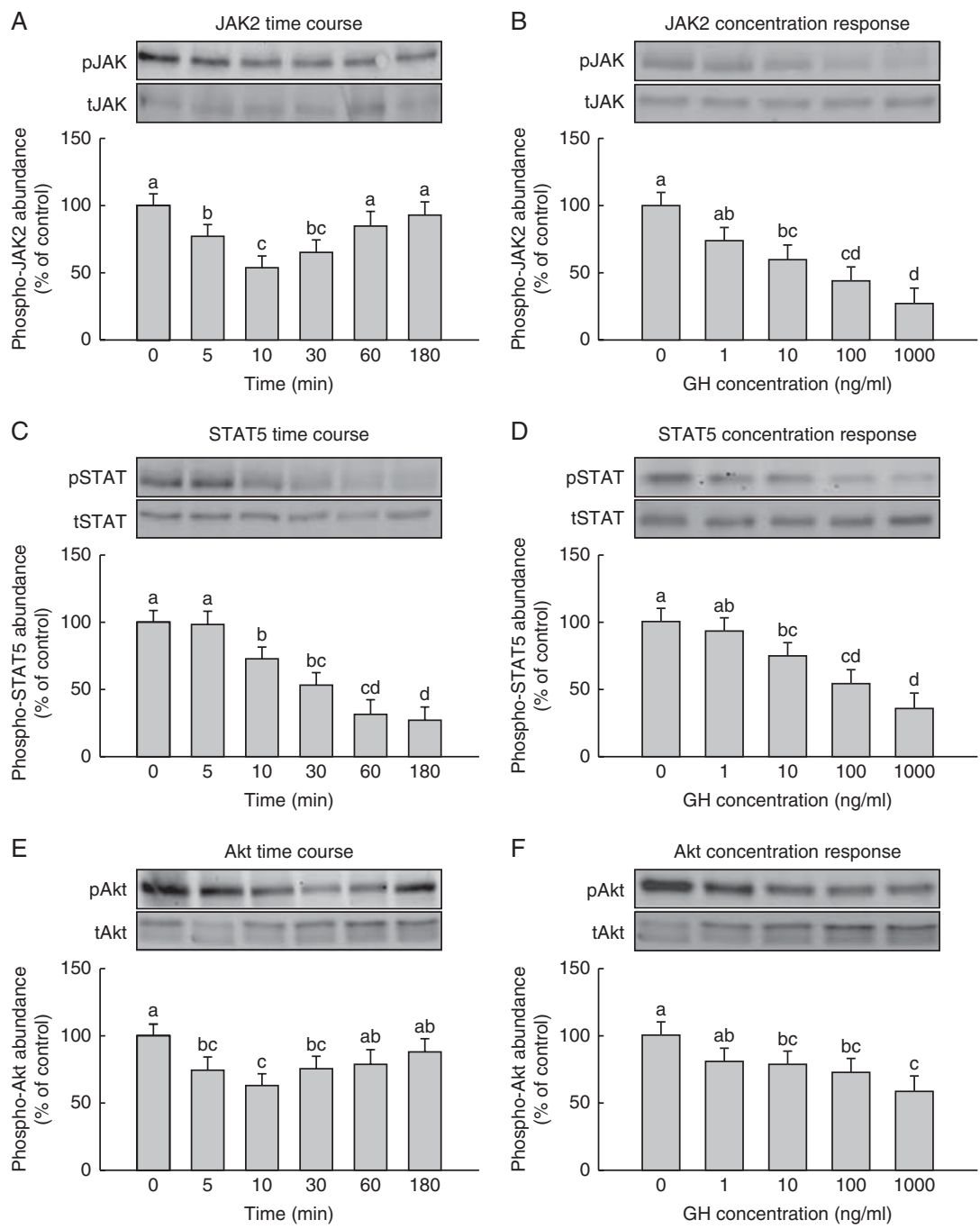

\section{Figure 4}

Effects of GH on the abundance of phosphorylated JAK2, STAT5, and protein kinase $B(A k t)$ in hepatocytes isolated from rainbow trout fasted for 7 days. (A, C, and E) Time-dependent phosphorylation of JAK2, STAT5, and Akt respectively in cells incubated with $100 \mathrm{ng} / \mathrm{ml} \mathrm{GH}$. (C, D, and F) Concentration-dependent phosphorylation of JAK2, STAT5, and Akt respectively in cells incubated in the absence or presence of $\mathrm{GH}$ for $30 \mathrm{~min}$

(control is $0 \mathrm{ng} / \mathrm{ml} \mathrm{GH}$ ). Cell lysates were separated by SDS-PAGE followed by western immunoblotting, and the blots were quantified with a FluorChem imager. The abundance of phosphorylated JAK2, STAT5, and Akt was normalized to total JAK2, STAT5, and Akt respectively. Data are presented as representative immunoblots (insets) and as means \pm s.E.M. $(n=4)$. Groups with different letters are significantly $(P<0.05)$ different. 
observed as GH concentration increased. Maximum deactivation occurred at $1000 \mathrm{ng} / \mathrm{ml} \mathrm{GH}$, resulting in a reduction in the phosphorylation state of JAK2, STAT5, and Akt to 25,35 , and $58 \%$ of the control respectively.

In contrast to the effect on JAK2, STAT5, and Akt, GH resulted in the activation of ERK and PKC. Significant activation of ERK by GH occurred within $10 \mathrm{~min}$ and persisted through $3 \mathrm{~h}$ (Fig. 5A). GH also significantly induced the phosphorylation of PKC within $10 \mathrm{~min}$, an effect that peaked after $60 \mathrm{~min}$ and then subsided back to control levels by $3 \mathrm{~h}$ (Fig. $5 \mathrm{C}$ ).

GH also activated ERK and PKC in a concentrationrelated manner (Fig. 5B and D). Significant phosphorylation was observed at a concentration of $10 \mathrm{ng} / \mathrm{ml} \mathrm{GH}$; maximal activation, increasing to $183 \%$ of control levels, was observed at $1000 \mathrm{ng} / \mathrm{ml}$. A similar profile was observed with the activation of PKC, for which significant phosphorylation was induced by a $\mathrm{GH}$ concentration of $10 \mathrm{ng} / \mathrm{ml}$ and maximal phosphorylation was achieved at $1000 \mathrm{ng} / \mathrm{ml}$.

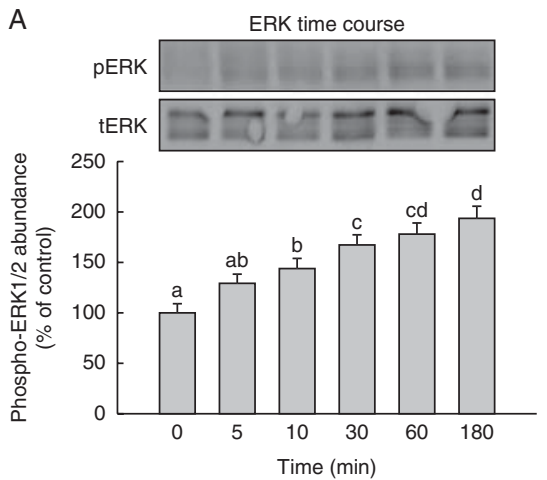

C
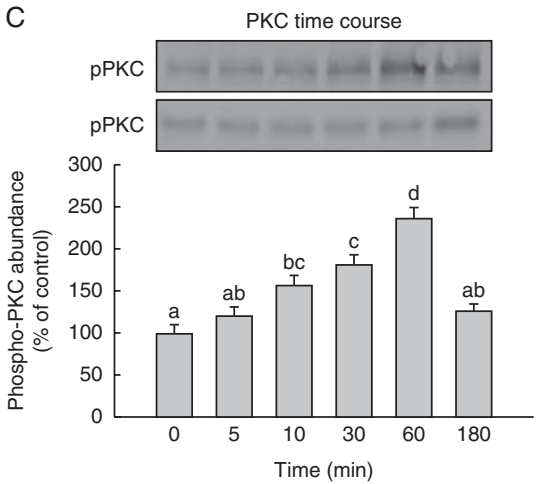

Figure 5

Effects of GH on the abundance of phosphorylated ERK and PKC in hepatocytes isolated from rainbow trout fasted for 7 days. (A and C) Timedependent phosphorylation of ERK and PKC respectively in cells incubated with $100 \mathrm{ng} / \mathrm{ml} \mathrm{GH}$. (B and D) Concentration-dependent phosphorylation of ERK and PKC respectively in cells incubated in the absence or presence of $\mathrm{GH}$ for $30 \mathrm{~min}$ (control is $0 \mathrm{ng} / \mathrm{ml} \mathrm{GH}$ ). Cell lysates were separated by

\section{Linkage of cell signaling elements to GH-stimulated lipolysis}

The linkage of specific cell signaling pathways to GHstimulated lipolysis and GH-stimulated HSL expression in isolated hepatocytes was studied using pharmacological inhibitors. The first series of experiments examined the effects of pathway blockade on lipolysis as measured by glycerol release (Fig. 6). As noted previously, GH $(100 \mathrm{ng} / \mathrm{ml})$ stimulated glycerol release over basal levels. Pretreatment of hepatocytes with the PKC inhibitor CC or with the PLC inhibitor U73122 completely blocked GH-stimulated lipolysis. The MEK inhibitor U0126 partially blocked GH-stimulated lipolysis. By contrast, the inhibition of JAK2 (with hex), PI3K (with LY294002), or Akt directly (with Carb) had no effect on GH-stimulated glycerol release from the hepatocytes.

The second series of experiments examined how signaling pathways mediate the activity state of HSL by evaluating their role in the phosphorylation of the

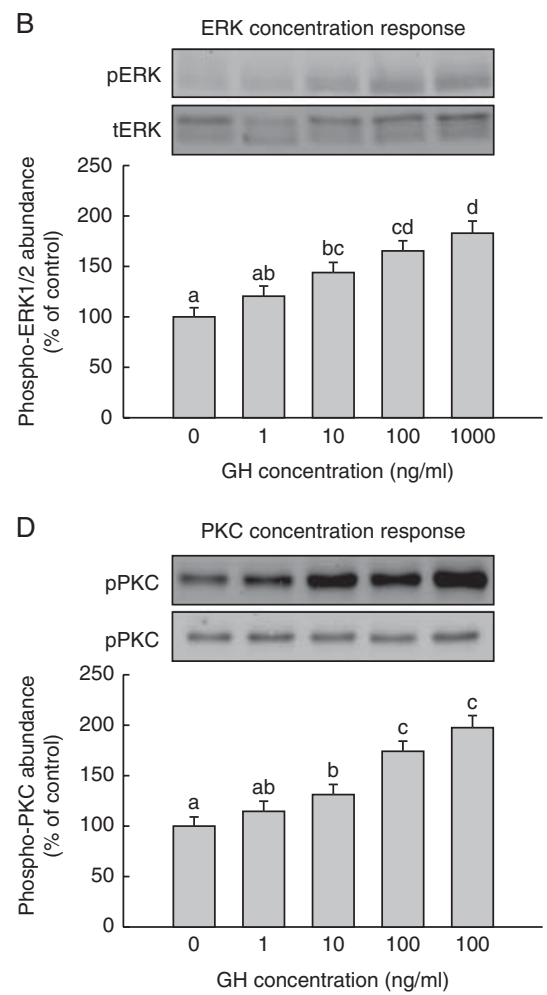

SDS-PAGE followed by western immunoblotting, and the blots were quantified with a FluorChem imager. The abundance of phosphorylated ERK $1 / 2$ and PKC $\alpha / \beta$ II was normalized to total ERK $1 / 2$ and $\beta$-actin respectively. Data are presented as representative immunoblots and as means \pm S.E.M. $(n=4)$. Groups with different letters are significantly $(P<0.05)$ different.

Published by Bioscientifica Ltd. 


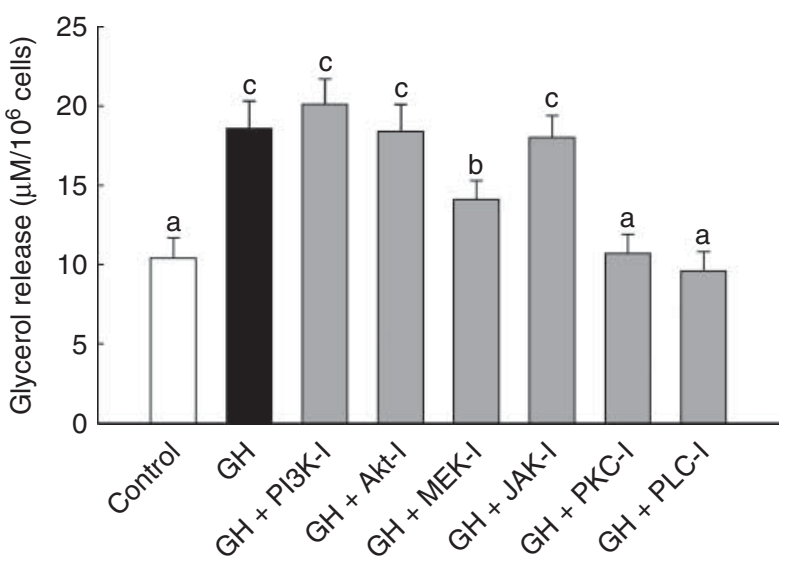

Figure 6

Effects of signaling element blockade on $\mathrm{GH}$-stimulated lipolysis as measured by glycerol release in hepatocytes isolated from rainbow trout fasted for 7 days. The cells were pretreated for $2 \mathrm{~h}$ with or without specific inhibitors for the following signaling elements: PI3K (10 $\mu \mathrm{M} \mathrm{LY294002),} \mathrm{Akt}$ (10 $\mu \mathrm{M}$ Carb), MEK (10 $\mu \mathrm{M}$ U0126), JAK2 (10 $\mu \mathrm{M}$ Hex), PKC (10 $\mu \mathrm{M} \mathrm{CC})$, and PLC (10 $\mu \mathrm{M}$ U73122); after which, the cells were treated with $100 \mathrm{ng} / \mathrm{ml} \mathrm{GH}$ for $6 \mathrm{~h}$ (control is $0 \mathrm{ng} / \mathrm{ml} \mathrm{GH}$ ). Data are presented as means \pm s.E.M. $(n=6)$. Groups with different letters are significantly $(P<0.05)$ different.

enzyme. GH stimulated ${ }^{32} \mathrm{P}$-phosphorylation of HSL (Fig. 7). The blockade of JAK (with Hex) had no effect on GH-stimulated phosphorylation of HSL, whereas the inhibition of ERK (with U0126) or PKC (with CC) blocked GH-stimulated phosphorylation of HSL (Fig. 7). In addition, the inhibition of PKA, a known regulator of HSL phosphorylation (Harmon et al. 1993; therefore used as a positive control), partially blocked GH-stimulated phosphorylation of HSL. The inhibition of PI3K (with LY294002) or Akt directly (with Carb) also had no effect on GH-stimulated phosphorylation of HSL (data not shown).

The third series of experiments examined the pathways mediating GH-stimulated mRNA expression (Fig. 8). The blockade of the ERK pathway with a MEK inhibitor (U0126) and the blockade of PLC (with U73122) partially reduced the expression of both HSL mRNAs. When the cells were pretreated with the PKC inhibitor (CC) followed by treatment with GH, the expression of HSL mRNA decreased below control levels. The blockade of P13K, Akt, JAK2, and STAT5 signaling elements did not affect GH-stimulated $H S L$ mRNA expression.

\section{Discussion}

The liver of teleost fish is a particularly opportune system to investigate the influence of GH on the mobilization of lipids because it is a significant lipid storage site with a well-characterized lipolytic system (Sheridan 1994) and it possesses a high abundance of GHRs (Reindl \& Sheridan 2012). The present results demonstrate that GH, at concentrations in the physiological range in the plasma of trout (Norbeck et al. 2007), stimulates lipolysis by activating HSL and by enhancing the de novo expression of HSL mRNAs. The results also confirm our starting hypothesis that GH-stimulated HSL activity and GHstimulated HSL mRNA expression are mediated through the ERK and PKC signaling pathways. These findings establish the mechanisms through which GH exerts comprehensive lipolytic actions and provides insight into how such actions may be integrated with other actions of $\mathrm{GH}$.

GH stimulates lipolysis by the activation of HSL. This is supported by the present observation that GH directly stimulated lipolysis in isolated hepatocytes, resulting in glycerol release. This observation is consistent with previous studies in mammalian adipose tissue (Gorin et al. 1990, Chavez et al. 2006) and in liver and adipose tissue of

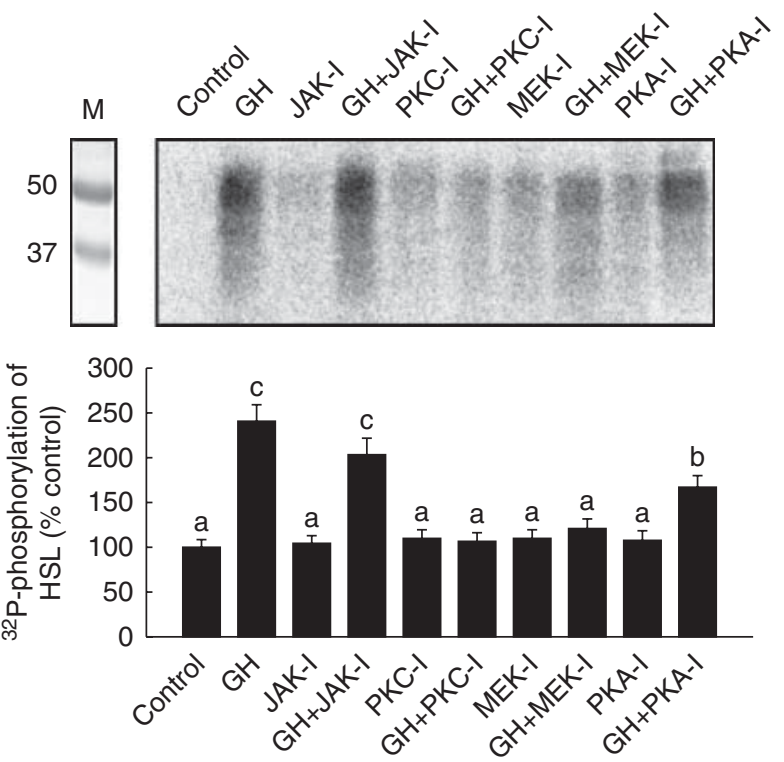

Figure 7

Effects of signaling element blockade on GH-stimulated phosphorylation of HSL in hepatocytes isolated from rainbow trout fasted for 7 days. Hepatocytes were preincubated for $3 \mathrm{~h}$ with $\left[{ }^{32} \mathrm{P}\right]$-monopotassium phosphate in the presence or absence of specific inhibitors for the following signaling elements: JAK2 $(10 \mu \mathrm{M} \mathrm{Hex}=\mathrm{JAK}-\mathrm{I})$, PKC $(10 \mu \mathrm{M}$ $\mathrm{CC}=$ PKC-I), MEK $(10 \mu \mathrm{M}$ U0126=MEK-I), and PKA $(10 \mu \mathrm{M} \mathrm{H}-89$ dihydrochloride $=$ PKA-l); after which the cells were treated with or without (control) GH at $100 \mathrm{ng} / \mathrm{ml}$ for another $3 \mathrm{~h}$. HSL was purified from the isolated hepatocytes by ammonium sulfate fractionation, and the phosphorylated enzyme was separated by SDS-PAGE and detected by autoradiography as described in the Materials and methods section. Data are presented as a representative autoradiogram (upper panel) and as means \pm s.E.M. $(n=3)$. 


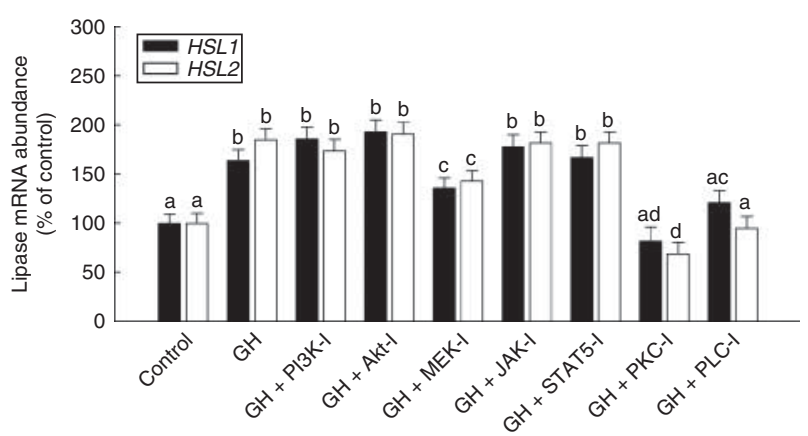

Figure 8

Effects of signaling element blockade on GH-stimulated expression of HSL1- and HSL2-encoding mRNAs in hepatocytes isolated from rainbow trout fasted for 7 days. Hepatocytes were preincubated for $2 \mathrm{~h}$ with or without specific inhibitors for the following signaling elements: PI3K $(10 \mu \mathrm{M}$ LY294002 $=$ PI3K-I), Akt $(10 \mu \mathrm{M}$ Carb=Akt-I), MEK $(10 \mu \mathrm{M}$ U0126=MEK-I), JAK2 $(10 \mu \mathrm{M}$ Hex $=$ JAK-I), STAT5 $(10 \mu \mathrm{M}$ Nico $=$ STAT-I), PKC $(10 \mu \mathrm{M}$ $\mathrm{CC}=$ PKC-I) , and PLC $(10 \mu \mathrm{M}$ U73122 $=$ PLC-I) and in the absence or presence of $\mathrm{GH}$ at $100 \mathrm{ng} / \mathrm{ml}$ for $6 \mathrm{~h}$ (control is $0 \mathrm{ng} / \mathrm{ml} \mathrm{GH}$ ); after which the cells were treated with $100 \mathrm{ng} / \mathrm{ml} \mathrm{GH}$ for $6 \mathrm{~h}$ (control is $0 \mathrm{ng} / \mathrm{ml} \mathrm{GH}$ ). Steady-state levels of mRNA were determined by quantitative real-time RT-PCR as described in the Materials and methods section. Data are presented as percent of change from controls and expressed as means \pm s.E.M. $(n=6)$. For a given $\mathrm{HSL}$ isoform, groups with different letters are significantly $(P<0.05)$ different.

fish (Sheridan 1994, Albalat et al. 2005) showing the GH-stimulated hydrolysis of stored TG and the release of glycerol and FAs and with studies in fish showing that GH increased the specific activity of hepatic HSL in vivo and in vitro (O'Connor et al. 1993, Sheridan 1994). Such lipolytic action underlies the increase in plasma FAs in mammals and fish following GH injection (Fain 1980, Lafontan \& Langin 2009). To our knowledge, the present study also reveals for the first time that GH-stimulated lipolysis is accompanied by the phosphorylation of HSL. In mammals (Watt \& Steinberg 2008) and fish (Sheridan 1994), HSL exists in two catalytic states and, upon activation by phosphorylation, hydrolyzes TG. Mutagenesis studies of mammalian HSLs have demonstrated that the phosphorylation of (in rat) $\operatorname{Ser}^{563}, \operatorname{Ser}^{600}, \operatorname{Ser}^{659}$, and $\operatorname{Ser}^{660}$ results in the activation of HSL, whereas the phosphorylation of Ser ${ }^{565}$ inhibits HSL activity (Yeaman 2004, Watt \& Steinberg 2008). The conservation of these residues in the two HSLs of rainbow trout (Kittilson et al. 2011) most probably explains the activation of hepatic HSL by phosphorylation observed in trout previously (Harmon et al. 1993) as well as the GH-stimulated activation of HSL observed in the present study.

GH signaling involves the activation of numerous signaling cascades, including JAK-STAT, ERK, PI3K/Akt, and PLC/DAG/PKC (Waters et al. 2006). Of these pathways, several current observations suggest that the activation of HSL by GH involves ERK and PKC. First, GH increased the abundance of phospho-ERK as well as of phospho-PKC. Second, specific blockade of the ERK pathway or PLC/PKC inhibited GH-stimulated lipolysis. Third, the blockade of the ERK pathway or PKC inhibited GH-stimulated phosphorylation of HSL. Taken together, these findings indicate that ERK and PKC mediate GH-stimulated activation of HSL. These findings are consistent with previous studies in mammals showing that GH activated PKC to promote lipolysis in fat pads isolated from rats (Gorin et al. 1990). Previous work in mammals have also shown that PKC could activate the ERK pathway (González-Yanes \& Sánchez-Margalet 2006) and that ERK is a proximate activator of HSL by the phosphorylation of $\operatorname{Ser}^{600}$ (Greenberg et al. 2001). In light of the current findings, it is reasonable to suggest that GH-stimulated lipolysis results from ERK activation of HSL mediated by PLC/PKC. The present findings also suggest that PKA mediates GH-stimulated lipolysis as evidenced by the partial inhibition of GH-stimulated phosphorylation of HSL in the presence of a specific PKA inhibitor. These findings are consistent with previous observations in mammals (Lafontan \& Langin 2009) and fish (Harmon et al. 1993) that PKA is a proximate activator of HSL. Mutagenesis studies in rats revealed that PKA phosphorylates HSL at Ser ${ }^{563}$, Ser ${ }^{659}$, and $\mathrm{Ser}^{660}$ (Yeaman 2004, Waters et al. 2006). These observations coupled with the previous observation that PKC can activate PKA (Fricke et al. 2004) and the current findings suggest that GH-stimulated lipolysis also results from PKA activation of HSL mediated by PLC/PKC. There is some suggestion that GH may accentuate the action of PKA by increasing the cytoplasmic pool of cAMP through the inhibition of $\mathrm{Gi} \alpha_{2}$; however, the specific effector(s) that transduce such action is (are) not known (Lafontan \& Langin 2009). It should also be noted that the possibility exists that PKC could directly activate HSL (as well as other lipases), but there is no evidence of this; however, other kinases such as cGMP-dependent protein kinase have been implicated in the activation of HSL (Yeaman 2004).

The current findings also suggest that GH-stimulated lipolysis is accompanied by the deactivation of JAK/STAT and PI3K/Akt. This conclusion is supported by GH reducing transiently the abundance of phospho-JAK2, phospho-STAT5, and phospho-Akt and by specific inhibition of JAK2, PI3K, or Akt having no effect on GH-stimulated lipolysis or GH-stimulated phosphorylation of HSL. These findings provide new insight into

Published by Bioscientifica Ltd. 
the signaling mechanisms that underlie the antagonism between lipolysis and antilipolysis/lipogenesis. At the nexus of this antagonism is Akt. Akt has been found to stimulate phosphodiesterase activity, which, in turn, reduces the cytoplasmic pool of cAMP and leads to the deactivation of PKA, dephosphorylation of HSL, and reduced lipolysis (Baragali et al. 2011). In addition, Akt activates AMP-activated protein kinase (Berggreen et al. 2009), which negatively regulates HSL by phosphorylation at $\operatorname{Ser}^{565}$ (Watt \& Steinberg 2008). Akt also regulates several lipogenic enzymes, including the activation of the acetyl-CoA carboxylase (Berggreen et al. 2009), the ratelimiting enzyme of FA synthesis. Given that Akt is a chief element of INS signaling (Caruso \& Sheridan 2011), it is through Akt that INS exerts its lipogenic and antilipolytic actions (Albalat et al. 2005, Chaves et al. 2011). The present findings suggest that by reducing the activation of Akt, GH shifts the balance of the antilipolysis/lipogenesislipolysis antagonism toward lipolysis by suppressing antilipolytic/lipogenic processes.

The current findings also indicate that GH stimulates lipolysis by increasing the expression of $H S L$-encoding mRNAs. Interestingly, the responsiveness of HSL1 to GH treatment appeared to be greater than that of HSL2. The existence of multiple HSL isoforms appears to be unique to teleost fish and the functional significance of the different forms is not clear; however, differences do exist in the intracellular domain of the predicted proteins (Kittilson et al. 2011) - differences that may be important for activation by different signal transduction systems and sufficient to explain the differential responsiveness to $\mathrm{GH}$. The ability of $\mathrm{GH}$ to promote the expression of lipases is consistent with previous observations in isolated rat adipocytes that GH-stimulated lipolysis was abolished by the inhibitors of RNA and protein synthesis (Fain 1980). To our knowledge, the current findings showing that the blockade of the ERK pathway or PLC/PKC inhibits GH-stimulated HSL expression indicate for the first time the mechanism(s) through which GH affects de novo HSL synthesis. The HSL (LIPE) promoter in mammals has been found to possess several elements that could be recognized by general transcription factors such as $S F 1, S p 1$, and C/EBPs as well as several other response elements, including glucose response element, fat response element, and a cAMP response element (Lampidonis et al. 2008). Given the previous observations that PKC activated PKA (Fricke et al. 2004) and that PKA increased HSL transcription via SF1 (Holsyz et al. 2011), it is reasonable to suggest that GH-stimulated HSL expression proceeds through a
PLC/PKC-PKA-SF1 pathway. Given that PKC activated ERK (Fricke et al. 2004) and that ERK activated c/EBP $\beta$ (Piwien-Pilipuk et al. 2002) and GH increases the expression of $\mathrm{c} / \mathrm{EBP} \beta$, including in rainbow trout (Lo et al. 2007), it is also reasonable to suggest that GH-stimulated HSL expression proceeds through a PLC/PKC-ERK-c/EBP $\beta$ pathway. The deactivation of Akt following $\mathrm{GH}$ treatment observed in the present study may also influence GH-stimulated HSL expression. For example, Akt plays a role in the dephosphorylation of c/EBP $\beta$ (Piwien-Pilipuk et al. 2002); therefore, by reducing the activation of Akt, the phosphorylation of $\mathrm{c} / \mathrm{EBP} \beta$ and the ensuing enhancement of HSL expression would be favored. Akt also leads to the activation of PDE (Chavez et al. 2006); by reducing the activation of Akt, there would be an increase in the cAMP pool and an increase in $H S L$ transcription via the cAMP response element.

The results of the present study help to explain the mechanisms that underlie fasting-associated lipid depletion. During periods of food deprivation, lipid depletion is accompanied by increases in plasma levels of $\mathrm{GH}$ in the face of reduced plasma levels of INS and insulin-like growth factor 1 (IGF1) in mammals and fish (Norbeck et al. 2007). We have recently shown that fasting-induced lipolysis in trout liver (as well as in adipose tissue and red and white skeletal muscle) was accompanied by the deactivation of Akt, JAK2, and STAT5 and by the activation of ERK and PKC (Bergan et al. 2012). In light of the present findings that GH-stimulated lipolysis was mediated by the activation of PKC and ERK in conjunction with the deactivation of PI3K-Akt and JAK-STAT, it is reasonable to conclude that GH promotes lipolysis during fasting by the activation of PKC and ERK and by the deactivation of PI3K/Akt and JAK2-STAT. In should be noted that the hepatocytes used in the present study were isolated from fish that were fasted for 7 days, a period of time previously shown to result in reduced plasma levels of INS and IGF1 and in elevated plasma levels of GH, which underscores the relevance of the findings for interpreting the actions of GH in the fasting state. The findings may also help to explain the mechanisms that underlie smoltification and premature transfer to seawater-associated depletion of lipids observed in salmonids - both of which occur in association with increases in plasma GH levels (Sheridan 1989).

In summary, these results indicate that $\mathrm{GH}$ promotes lipolysis by enhancing the expression of HSL-encoding mRNAs as well as by phosphorylating HSL via the activation of PKC and ERK.

Published by Bioscientifica Ltd. 


\section{Declaration of interest}

The authors declare that there is no conflict of interest that could be perceived as prejudicing the impartiality of the research reported.

\section{Funding}

This research was supported by a grant from the National Science Foundation, USA (IOS 0920116) to M A S.

\section{Acknowledgements}

The authors thank Elle Kvam, Chad Walock, Dillon Marquart, Lindsey Norbeck, Andrea Hanson, Lincoln Martin, and Elizabeth Ellens for their assistance. They also thank Prof. Akiyosi Takahasi and $\mathrm{Dr}$ Shiunsuke Moriyama for generously providing salmonid GH.

\section{References}

Albalat A, Gomez-Requeni P, Rojas P, Medale F, Kaushik S, Vianen GJ, Van den Thillart G, Gutiérrez J, Perez-Sanchez J \& Navarro I 2005 Nutritional and hormonal control of lipolysis in isolated gilthead sea bream (Sparus aurata) adipocytes. American Journal of Physiology 289 R259-R265. (doi:10.1152/ajpregu.00574.2004)

Albalat A, Saera-vila A, Capilla E, Gutierrez J, Perez-Sanchez J \& Navarro I 2007 Insulin regulation of lipoprotein lipase (LPL) activity and expression in gilthead sea bream (Sparus aurata). Comparative Biochemistry and Physiology. Part B, Biochemistry \& Molecular Biology 148 151-159. (doi:10.1016/j.cbpb.2007.05.004)

Baragali A, Ghè C, Arnoletti E, Granata R, Ghigo E \& Muccioli G 2011 Acylated and unacylated ghrelin attenuate isoproterenol-induced lipolysis in isolated rat visceral adipocytes through activation of phosphoinositide 3-kinase $\gamma$ and phosphodiesterase 3B. Biochimica et Biophysica Acta 1811 386-396. (doi:10.1016/j.bbalip.2011.03.001)

Bergan HB, Kittilson JD \& Sheridan MA 2012 Nutrition-regulated lipolysis in rainbow trout (Oncorhynchus mykiss) is associated with alteration in the ERK, PI3K-Akt, JAK-STAT, and PKC signaling pathways. General and Comparative Endocrinology 176 367-376. (doi:10.1016/j.ygcen. 2011.12.013)

Berggreen C, Gormand A, Omar B, Degerman E \& Goransson O 2009 Protein kinase $\mathrm{B}$ activity is required for the effects of insulin on lipid metabolism in adipocytes. American Journal of Physiology 296 E635-E646. (doi:10.1152/ajpendo.90596.2008)

Bjornsson BT, Johansson V, Benedet S, Einarsdottir IE, Hildahl J, Agustsson T \& Jonsson E 2004 Growth hormone endocrinology of salmonids: regulatory mechanisms and mode of action. Fish Physiology and Biochemistry 27 227-242. (doi:10.1023/B:FISH.0000032728.91152.10)

Carrel AL \& Allen DB 2000 Effects of growth hormone on adipose tissue. Journal of Pediatric Endocrinology \& Metabolism 13 1003-1009.

Caruso MA \& Sheridan MA 2011 New insights into the signaling system and function of insulin in fish. General and Comparative Endocrinology 173 227-247. (doi:10.1016/j.ygcen.2011.06.014)

Chaves VE, Frasson D \& Kawashita NH 2011 Several agents and pathways regulate lipolysis in adipocytes. Biochimie 93 1631-1640. (doi:10.1016/ j.biochi.2011.05.018)

Chavez JA, Gridley S, Sano H, Lane WS \& Lienhard GE 2006 The 47 kDa Akt substrate associates with phosphodiesterase $3 \mathrm{~B}$ and regulates its level in adipocytes. Biochemical and Biophysical Research Communications 324 1218-1222. (doi:10.1016/j.bbrc.2006.02.091)

Fain JN 1980 Hormonal regulation of lipid mobilization from adipose tissue. In Biochemical Action of Hormones, pp 119-203. Ed G Litwack. New York: Academic Press.
Fricke K, Heitland A \& Maronde E 2004 Cooperative activation of lipolysis by protein kinase A and protein kinase C pathways in 3T3-L1 adipocytes. Endocrinology 145 4940-4947. (doi:10.1210/en.2004-0803)

González-Yanes C \& Sánchez-Margalet V 2006 Signalling mechanisms regulating lipolysis. Cellular Signalling 18 401-408. (doi:10.1016/ j.cellsig.2005.08.009)

Gorin E, Tai L, Honeyman TW \& Goodman HM 1990 Evidence for a role of protein kinase $\mathrm{C}$ in the stimulation of lipolysis by growth hormone and isoproterenol. Endocrinology 126 2973-2982. (doi:10.1210/ endo-126-6-2973)

Greenberg AS, Shen WJ, Muliro K, Patel S, Souza SC, Roth RA \& Kraemer FB 2001 Stimulation of lipolysis and hormone-sensitive lipase via the extracellular signal-regulated kinase pathway. Journal of Biological Chemistry 276 45456-45461. (doi:10.1074/jbc.M104436200)

Harmon JS, Michelsen KG \& Sheridan MA 1991 Purification and characterization of hepatic triacylglycerol lipase isolated from rainbow trout. Fish Physiology and Biochemistry 9 361-368. (doi:10.1007/ BF02265156)

Harmon JS, Rieniets LM \& Sheridan MA 1993 Glucagon and insulin regulate lipolysis in trout liver by altering phosphorylation of triacylglycerol lipase. American Journal of Physiology 265 255-260.

Holsyz M, Derebecka-Holszy N \& Trzeciak WH 2011 Transcription of LIPE gene encoding hormone-sensitive lipase/cholesteryl esterase is regulated by SF-1 in human adrenocortical cells: involvement of protein kinase A signal transduction pathway. Journal of Molecular Endocrinology 46 29-36. (doi:10.1677/JME-10-0035)

Kittilson JD, Reindl KM \& Sheridan MA 2011 Rainbow trout (Oncorhynchus mykiss) possess two hormone-sensitive lipase-encoding mRNAs that are differentially expressed and independently regulated by nutritional state. Comparative Biochemistry and Physiology. Part A, Molecular \& Integrative Physiology 158 52-60. (doi:10.1016/j.cbpa.2010.09.010)

Lafontan M \& Langin D 2009 Lipolysis and lipid mobilization in human adipose tissue. Progress in Lipid Research 48 275-297. (doi:10.1016/ j.plipres.2009.05.001)

Lampidonis AD, Stravopodis DJ, Voutsinas GE, Messini-Nikolaki N, Stefos GC, Margaritis LH, Argyrokastritis A, Bizelis I \& Rogdakis E 2008 Cloning and functional characterization of the $5^{\prime}$ regulatory region of ovine hormone sensitive lipase (HSL) gene. Gene $\mathbf{4 2 7}$ 65-79. (doi:10.1016/j.gene.2008.09.001)

Lo JH, Chiou PP, Lin CM \& Chen TT 2007 Molecular cloning and expression analysis of rainbow trout (Oncorhynchus mykiss) CCAAT/ enhancer binding protein genes and their response to induction by $\mathrm{GH}$ in vitro and in vivo. Journal of Endocrinology 194 393-406. (doi:10.1677/ JOE-07-0085)

Mommsen TP, Moon TW \& Walsh PJ 1994 Hepatocytes: isolation, maintenance, and utilization. In Biochemistry and Molecular Biology of Fish, pp 355-373. Eds PW Hochachka \& TP Mommsen. New York: Elsevier Science.

Norbeck LA, Kittilson JD \& Sheridan MA 2007 Resolving the growthpromoting and metabolic effects of growth hormone: differential regulation of GH-IGF-I system components. General and Comparative Endocrinology 151 332-341. (doi:10.1016/j.ygcen.2007.01.039)

Norrelund H 2005 The metabolic role of growth hormone in humans with particular reference to fasting. Growth Hormone \& IGF Research 15 95-122. (doi:10.1016/j.ghir.2005.02.005)

O'Connor PK, Reich B \& Sheridan MA 1993 Growth hormone stimulates hepatic lipid mobilization in rainbow trout, Oncorhynchus mykiss. Journal of Comparative Physiology 163 427-431.

Piwien-Pilipuk G, Huo JS \& Schwatz J 2002 Growth hormone signal transduction. Journal of Pediatric Endocrinology \& Metabolism 15 771-786.

Reindl KM \& Sheridan MA 2012 Peripheral regulation of the growth hormone-insulin-like growth factor system in fish and other vertebrates. Comparative Biochemistry and Physiology. Part A, Molecular \& Integrative Physiology 163 231-245. (doi:10.1016/j.cbpa.2012.08.003) 
Reindl KM, Kittilson JD, Bergan HE \& Sheridan MA 2011 Growth hormonestimulated insulin-like growth factor-1 expression in rainbow trout (Oncorhynchus mykiss) hepatocytes is mediated by ERK, PI3K-AKT, and JAK-STAT. American Journal of Physiology 301 R236-R243.

Sheridan MA 1988 Lipid dynamics in fish: aspects of absorption, transportation, deposition and mobilization. Comparative Biochemistry and Physiology. B, Comparative Biochemistry 90 679-690. (doi:10.1016/ 0305-0491(88)90322-7)

Sheridan MA 1989 Alterations in lipid metabolism accompanying smoltification and seawater adaptation of salmonid fish. Aquaculture 82 191-203. (doi:10.1016/0044-8486(89)90408-0)

Sheridan MA 1994 Regulation of lipid metabolism in poikilothermic vertebrates. Comparative Biochemistry and Physiology.
B, Comparative Biochemistry 107 495-508. (doi:10.1016/0305-0491 (94)90176-7)

Waters MJ, Hoang HN, Fairlie DP, Pelekanos RA \& Brown RJ 2006 New insights into growth hormone action. Journal of Molecular Endocrinology 36 1-7. (doi:10.1677/jme.1.01933)

Watt MJ \& Steinberg GR 2008 Regulation and function of triacylglycerol lipases in cellular metabolism. Biochemical Journal 414 313-325. (doi:10.1042/BJ20080305)

Watt MJ \& Spriet LL 2010 Triacylglycerol lipase and metabolic control: implication for health and disease. American Journal of Physiology 299 E162-E168. (doi:10.1152/ajpendo.00698.2009)

Yeaman SJ 2004 Hormone-sensitive lipase - new roles for an old enzyme. Biochemical Journal 79 11-22. (doi:10.1042/BJ20031811)

Received in final form 17 June 2013

Accepted 19 June 2013

Accepted Preprint published online 19 June 2013 http://jme.endocrinology-journals.org DOI: 10.1530/JME-13-0039
(C) 2013 Society for Endocrinology Printed in Great Britain
Published by Bioscientifica Ltd. 